\title{
A Method for Expression of Perfume by Sensory Terms (Part 2)
}

\author{
Toshiei Koyanagi, Satoko Horikoshi, Arata Yamakawa
}

\begin{abstract}
In these days various series of perfumes are on the market. It is very important for cosmetic companies to know what types of perfumes are preferred, and what kind of impression those perfumes give. On the 13th Scientific Seminer of the SCCJ we published the results of our research about the evolution of the sensory terms (that is image of perfumes) to the expert terms of perfumes, under the title of "The Development of the Image Evolution of the Sensory Terms on Creating Perfumery". We have used the results in practice and we have had a good achievement in developing fresh type of perfume as to Citrus types, and Oriental types of perfumes as to Animal and Balsam types. However, it turned out that it failed in developing Floral types, Aldehyde Floral types and Chypre types of perfumes. We found that some gaps existed between perfumers and consumers in image formation to the perfumes.

Now we carried out the sensory evaluation with 21 perfumes by 43 consumer-panels and 9 perfumer-panels using 20 sensory terms and 15 expert terms (for only perfumers) to grasp the difference between consumer-panels and perfumer pannels.

Consequently it proved that the perfumers are superior to consumers because the variance of evaluation data is small and the discriminating ability is high, while as to consumers the varjance of evaluation data is large and the discriminating ability is low. However after classifying the 43 consumer-panels using cluster analysis, they were divided into 5 clusters, and the variance of evaluation data becomes small and the discriminating ability becomes high in each cluster.

As to the terms based on the concept of Light-Heavy, the consumers' evaluation data in each cluster corresponds to that of the perfumers'. However, as to the other terms, the evaluation data between the consumers and the perfumers was different. Only one cluster never corresponds to the concept of perfumes. It is concluded that each cluster has a character, then it is necessary for perfumers to create perfumes aiming at one or some clusters, considering each cluster's character.
\end{abstract}

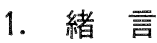

第13回研究討論会において“創香に稀けるイメージ展 開技法の開発”之題して発表した開発技法を，その後実 用面に执いて利用してきたが，シトラスを中心としたフ レッシュタイプ, アニマルやバルサムを中心としたオリ エンタルタイプの香りの開発に関しては高い達成率が得

株小林コ一セ一研究所: 鼠京都北区栄町 48-18

Kobayashi Kose Co., Ltd. Research Laboratory: 48-18, Sakae-cho, Kita-ku, Tokyo Japan.
られてきた。しかしフローラル，アルデヒドフローラル やシプレタイプに対しては高い達成率が得られない事が 判明してきた。

すなわち, 香りの評価に括いて専門パネルと一般パネ ル間に共通認識が認められる用語と認められないものが 存在する事を意味している。ぬた一般パネル内に㨐いて もあるいパネル群は專門パネルと一致している場合があ り，一般パネル間の評価にバラッキがあることる明らか になってきた。

そこで今回, 香りの表現に関してどの項目が一般パネ 
ルと専門パネルの間に一致性が見い出され，どの項目に 共通性がないのか探求することを目的として，一般パネ ル43名, 専門パネル9名, 香水 21 品, 官能評洒用語 20 項 目を用いて実験を行なった結果，新知見が得られたので 報告する次第でめる。

\section{2. 実験内容}

1）官能評価用語調查：カトレア会員342名72項目, 一 20項目選定1985年 4 月～5月

2）官能評価実施年月日：1985年 8 月 9 月
3）パネル：一般パネル43名, 専門パネル9名 (パヒューー)

4) 評価の場所：無臭評価室

5) テスト方法：匂小紙(10分後評価) 3 香水 $/ 1$ 回 （30分午前中） 2 回 $/ 1 \mathrm{~W}$ パネルごとに評価 実施ランダマイズ表作成

6）解析手法：クラスター分析（ウォード法）因子 分析

7）サンプル：ハーマンライマ一社の分類表より各 タイプ 3 品を選択した

A List of 21 Samples

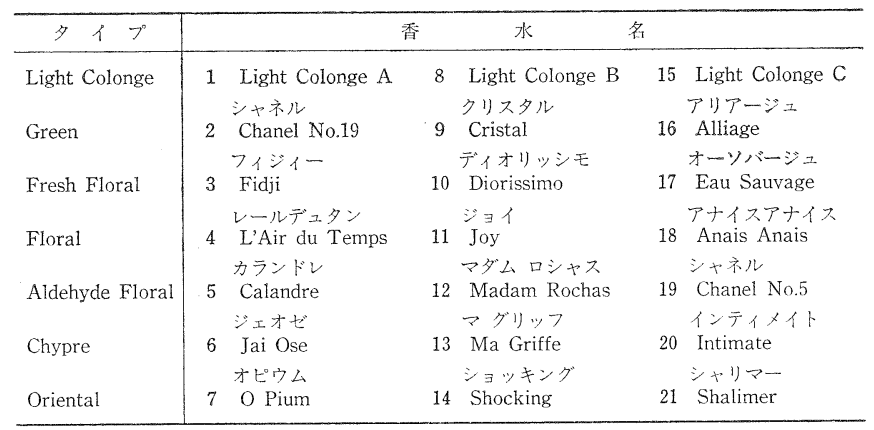

\begin{tabular}{|c|c|c|c|c|c|c|c|}
\hline \multicolumn{2}{|r|}{$\langle N=342\rangle$} & $(\%)$ & $10 \% 20 \% 30 \% \quad 40 \% 50 \% 60 \%$ & \multicolumn{3}{|r|}{$(\%)$} & $10 \% \quad 20 \% 30 \% \quad 40 \% \quad 50 \% \quad 60 \%$ \\
\hline (1) & 自然な & $213(62.3)$ & & $\begin{array}{l}37 \\
(38)\end{array}$ & $\begin{array}{l}\text { 椧たい } \\
\text { 放やかな }\end{array}$ & & $=$ \\
\hline $\begin{array}{l}2 \\
3\end{array}$ & $\begin{array}{l}\text { 人工的な } \\
\text { 表面的な }\end{array}$ & $\begin{array}{r}20(5.8) \\
7(2.0)\end{array}$ & 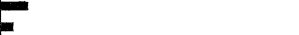 & 39 & 拡がりのある & $\begin{array}{r}248(72.5) \\
29(8.5)\end{array}$ & 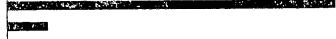 \\
\hline 4 & 深みのある & $68(19.9)$ & & 40 & 力強い & $7(2.0)$ & 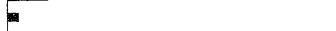 \\
\hline (5) & 甘い & $161(49.1)$ & & 41 & ケミカルな & $19(5.6)$ & $5 x$ \\
\hline 6 & にがい & $22(6.4)$ & $=$ & 42 & 印象的な & $42(12.3)$ & - \\
\hline 7 & からい & $17(5.0)$ & $=$ & 43 & 親しみやすい & $83(24.3)$ & - 2 - \\
\hline (8) & ヤング的な & $53(15.5)$ & & 44 & セクシーな & $68(19.9)$ & \\
\hline (9) & アダルト的な & $56(16.4)$ & 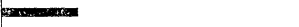 & 45 & メディカルな & $16(4.5)$ & $=$ \\
\hline 10 & シンプルな & $89(26.8)$ & & 46 & 石瞼のような & $133(38.9)$ & \\
\hline 11 & 複雑な & $14(4.1)$ & $\operatorname{man}$ & (47) & 清潔感のような & $177(51.8)$ & \\
\hline (12) & 重い2 & $26(7.6)$ & $\infty$ & (48) & 高級な & $83(24.3)$ & 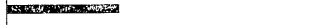 \\
\hline (13) & 軽い & $83(24.3)$ & & (49) & 洗練された & $94(27.5)$ & 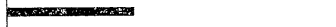 \\
\hline 14 & 幻想的 & $45(13.2)$ & parasinger & 50 & ロマンティックな & $99(28.9)$ & 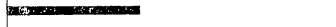 \\
\hline 15 & 現奏的 & $6(1.8)$ & $=$ & 51 & 現代的な & $20(5.8)$ & $=$ \\
\hline 16 & 斬新な & $15(4.4)$ & $m$ & 52 & 古典的な & $38(11.1)$ & m \\
\hline 17 & ありふれた & $47(13.7)$ & 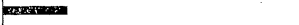 & (53) & やざしい & $127(37.1)$ & \\
\hline 18 & 丸みのある & $55(16.1)$ & aras & 54 & 調和のとれた & $53(15.5)$ & \\
\hline 19 & シャープな & $59(17.3)$ & 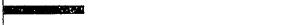 & 55 & ふくらみのある & $31(9.1)$ & \\
\hline 20 & 素朴な & $50(14.6)$ & 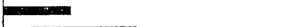 & (56) & あきのこない & $113(33.0)$ & \\
\hline (21) & 華やかな & $99(28.9)$ & & (57) & 上品な & 181(52.9) & 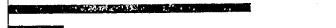 \\
\hline (22) & 個性的な & $74(21.6)$ & & 58 & 気㪕な & $41(12.0)$ & 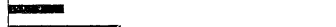 \\
\hline 23 & 平凡な & $37(10.8)$ & man & 59 & 健康的な & $83(24.3)$ & \\
\hline (24) & 男性的な & $66(19.3)$ & is & 60 & きりげない & 135(39.5) & \\
\hline (25) & 女性的な & $143(41.8)$ & and & 61 & おちついた & $84(24.6)$ & $\mathrm{s}$ \\
\hline 26 & 繊細な & $58(17.0)$ & Jumere rines & 62 & Lつこい & $69(20.2)$ & \\
\hline 27 & 粗野な & $7(2.0)$ & $\mathbf{a}$ & 63 & くせのある & $51(14.9)$ & Drancestax \\
\hline 28 & 明るい & $42(12.3)$ & 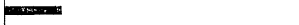 & (64) & 花の上うな & $152(44.4)$ & 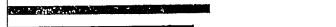 \\
\hline 29 & 暗い2 & $7(2.0)$ & $\boldsymbol{m}$ & (65) & フルーツのような & $139(40.6)$ & $\sin 2$ \\
\hline 30 & 躍動的 & $26(7.6)$ & $\operatorname{man}$ & 66 & スパイシーな & $49(14.9)$ & 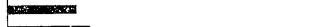 \\
\hline 31 & 静的な & $20(5.8)$ & $\sin$ & 67 & 黑っばいる & $61(17.8)$ & masisen \\
\hline (32) & 湿厚な & $63(18,4)$ & & 68 & 動物的な & $40(11.7)$ & $\sin$ \\
\hline 33 & 淡白な & $41(12,0)$ & 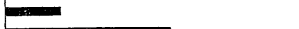 & 69 & 夜を感じさせる & $23(6.7)$ & 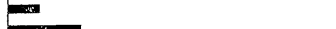 \\
\hline 34 & ソフトな & $123(36.0)$ & & (70) & 青くさい & $54(15.8)$ & \\
\hline 35 & 固い & $10(2.9)$ & a & 71 & ユニセックスな & $38(11.1)$ & ander \\
\hline 36 & 暖が & $29(8.5)$ & $\sin$ & 72 & 都会的な & $44(12.9)$ & \\
\hline
\end{tabular}

Fig.-1 Results of Searching the Sensory Terms of Rerfumes 


\section{3. 結果と考察}

\section{1 香りの官能評価用語調查結果}

カトレア会員 (一般消費者) に香りのイメージを表現 する言葉として理解できる用語のアンケート調査結果を

Fig.-1に示した。

$25 \%$ 学選択基集として判断し，同類語として判断して 良いものほまとめ, その中から必要に応じて選択し，25 $\%$ 以下の用語でも過去の調査や評価等で必要と判断した ๖のは採用し, 計26項目とした。民站語ほ 1 対の用語と
みなし最終的に20項目を官能評洒用語として用いた。

\section{$3.2 \mathrm{~S} ・ \mathrm{D}$ 結果と（プロフィール）の比較}

専門パネルのS・D結果と一般パネルの結果を Fig.-

2, Fig.-3に示した。

この結果より，専門パネルの片が一般パネルよりサン プルを大きく左右にふって和り識別力の㐫る事を示して いる。

\section{3 平均值の信頼性の検討}

3.2 の結果より軍門パネルの方がサンプル識別能力が 㐫り，一般パネルほ中心化傾向となり劣る結果となった

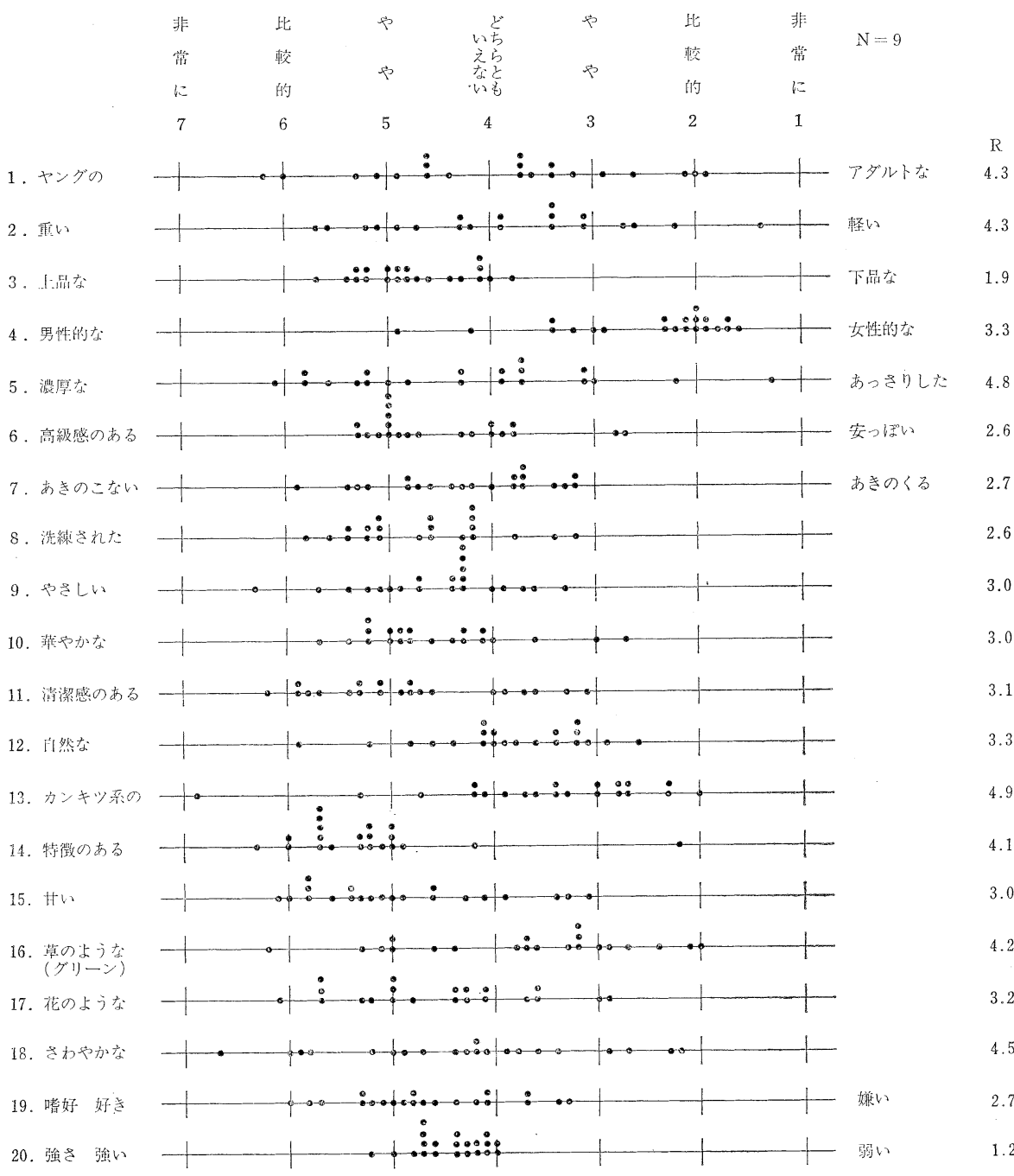

Fig.-2 Profile of Distribution of 21 Samples (Perfumers' Data) 


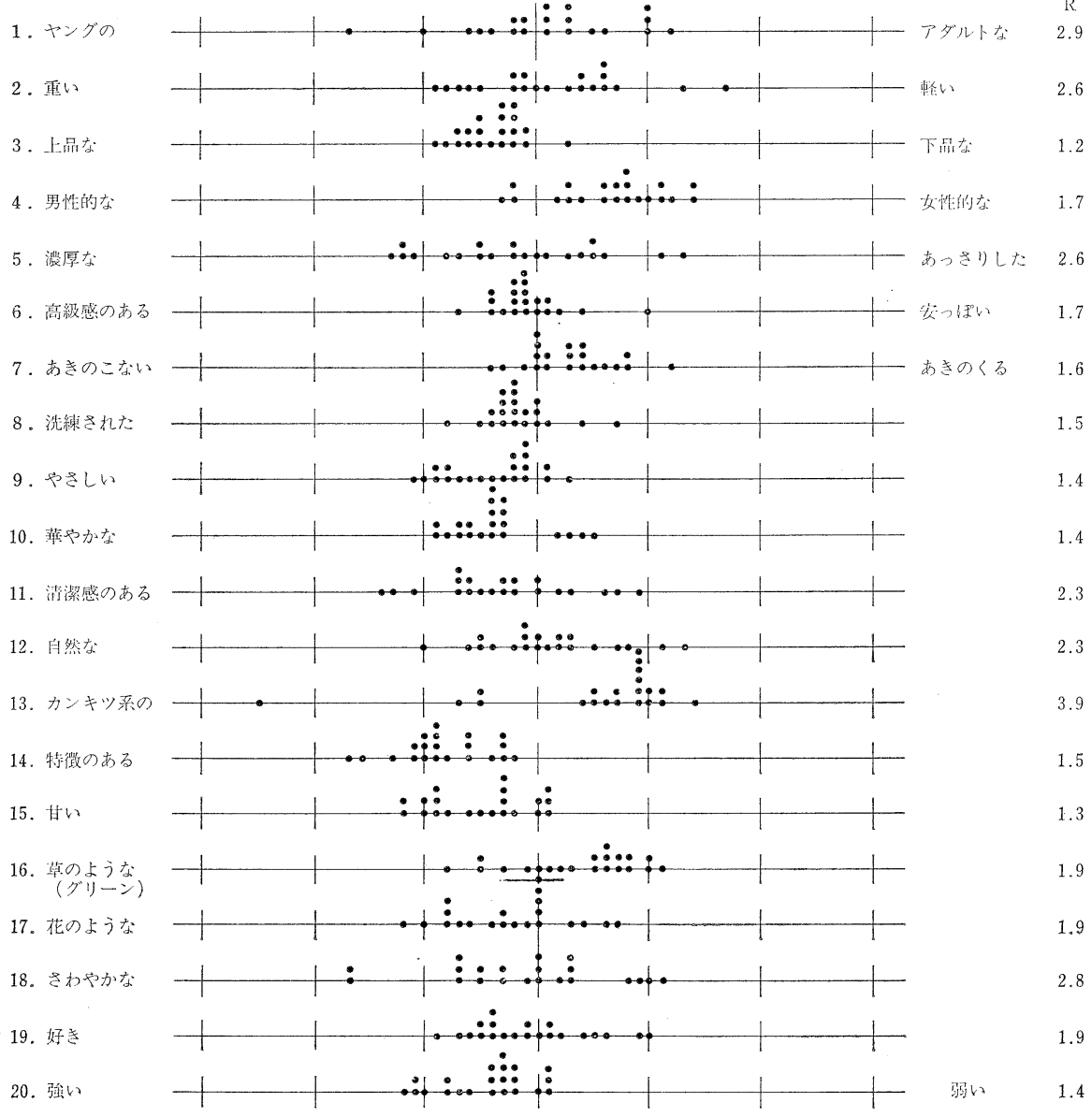

Fig.-3 Profile of Distribution of 21 Samples (Consumers' Data)

が, この理由として，

1) 官能栖価用語に対する共通認識がないためパネル 間のバラッキが大きく, その結果平均值が中心傾向にな る場合

2) 評価においてあまり自信がないため“やや○○ だ”といったように初めからどちらとも言光ない(4 点)

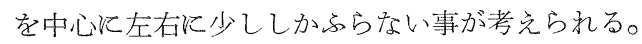

そこで各々の官能評価用語に括けるパネル間のバラッ キを標準偏差という值で見てみる（Table-1）

Table-1 より最もバラッキが大きい項目は嘴好であ
り, 從来の知見から官能評価汇対する反応子好きなサン

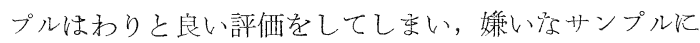
対してはカラくつける傾向があるため, 一般パネル43名 を同一集団でなく異質集団の集合体と又なし，嗒好とい う総合特性値を用いてクラスター分析によって分類を試 みた（Fig.-4)。この結果，6クラス父一が得られた が，第 6 クラスターは 3 名と人数も少なく、またアンチ 香水派タイプなため今後の解析の対象外亡した。

\section{4 クラスター分析による分類効果の険証}

3.4.1 クラスターの平均值の信頼性の検討 
Table-1 Standard Deviation of 43 Consumer on each block in 21 Samples $\times 20$ Sensory Terms.

\begin{tabular}{|c|c|c|c|c|c|c|c|c|c|c|c|c|c|c|}
\hline \multirow{2}{*}{\multicolumn{2}{|c|}{ 官 能 評 価 用 語 }} & 1 & $\cdots$ & 6 & 7 & 8 & 9 & 10 & $\cdots$ & 15 & 16 & $\cdots$ & 21 & \multirow[b]{2}{*}{$\begin{array}{c}\sigma>1.5 \\
\sigma \\
\text { 数 }\end{array}$} \\
\hline & & 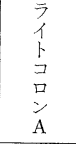 & $\cdots$ & $\begin{array}{l}シ \\
z \\
才 \\
セ ゙\end{array}$ & $\begin{array}{l}\pi \\
E^{\circ} \\
\dot{\eta} \\
厶\end{array}$ & 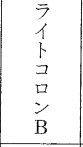 & $\begin{array}{l}7 \\
\text { I } \\
\text { 多 } \\
\text { 列 }\end{array}$ & $\begin{array}{c}\text { デ } \\
1 \\
\text { 才 } \\
y \\
y \\
y \\
\vdots \\
z\end{array}$ & $\cdots$ & 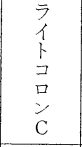 & $\begin{array}{l}p \\
\text { p } \\
p \\
1 \\
\xi \\
1\end{array}$ & $\cdots$ & $\begin{array}{l}\text { シ } \\
+ \\
1 \\
⿱ 乛 \\
1\end{array}$ & \\
\hline 1 & ヤング $\leftrightarrow$ アダルト & 1.407 & $\cdots$ & $(1.587)$ & 1.348 & $〔 1.548\rceil$ & 1.325 & [1.521] & $\ldots$ & $(1.543)$ & $(1.673)$ & $\cdots$ & 1.239 & 6 \\
\hline 2 & 重い $\leftrightarrow$ 㪕い & 1.211 & $\cdots$ & $(1.574)$ & $(1.511)$ & 1.009 & {$[1.507]$} & 1.428 & $\cdots$ & 1.335 & 1.309 & $\cdots$ & 1.407 & 3 \\
\hline 3 & 上品な $\leftrightarrow$ 下品な & 1.177 & $\cdots$ & 1.207 & 1.231 & 0.986 & 1.313 & 1.344 & $\cdots$ & 0.945 & 1.075 & $\cdots$ & 1.423 & 0 \\
\hline 4 & 男性的 ↔ 女性的 & 1.097 & $\cdots$ & 1.431 & $\lceil 1.862\rceil$ & 1.284 & 1.468 & 1.478 & $\cdots$ & 1.199 & 1.445 & $\cdots$ & $(1.675)$ & 5 \\
\hline 5 & 嶩厚な ↔ あっさりした & 1.370 & $\cdots$ & $(1.515)$ & 1.456 & 1.322 & $(1.525]$ & {$[1.692]$} & $\cdots$ & $\{1.679\}$ & 1.452 & $\cdots$ & 1.353 & 4 \\
\hline 6 & 高級感 ↔ 安っぽい & 1.271 & $\cdots$ & 1.030 & 1.361 & 1.001 & 1.109 & $\{1.579]$ & $\cdots$ & 1.044 & 1.138 & $\cdots$ & 1.477 & 1 \\
\hline 7 & あきのこない↔あきのくる & 1.338 & $\cdots$ & 1.386 & {$[1.640]$} & {$[1.526]$} & {$[1.518]$} & 1.378 & $\cdots$ & {$[1.680]$} & 1.450 & $\cdots$ & 1.464 & 7 \\
\hline 8 & 洗練された & 1.265 & $\cdots$ & 1.176 & 1.338 & 1.346 & 1.303 & 1.412 & $\cdots$ & 1.278 & 1.277 & $\cdots$ & {$[1.512]$} & 1 \\
\hline 9 & やきしい & 1.247 & $\cdots$ & $(1.523)$ & 1.462 & 1.398 & [1.624] & 1.379 & $\cdots$ & 1.313 & 1.280 & $\cdots$ & {$[1.706]$} & 4 \\
\hline 10 & 華やかな & 1.314 & $\cdots$ & 1.298 & 1.311 & 1.086 & 1.447 & 〔1.655] & $\cdots$ & 1.403 & 1.224 & $\cdots$ & {$[1.548]$} & 3 \\
\hline 11 & 清潔感のある & 1.218 & $\ldots$ & 1.477 & 1.434 & 1.268 & 1.476 & $(1.618]$ & $\cdots$ & $(1.509]$ & $\lceil 1.555]$ & $\cdots$ & 1.263 & 4 \\
\hline 12 & 自然な & 1.321 & $\cdots$ & 1.472 & 1.431 & 1.464 & $(1.517)$ & 1.444 & $\cdots$ & 1.455 & {$[1.627]$} & $\ldots$ & 1.089 & 2 \\
\hline 13 & カンキツ系の & 1.231 & $\cdots$ & 1.310 & 1.348 & {$[1.559]$} & 1.483 & 1.419 & $\cdots$ & 1.139 & {$[1.578]$} & $\cdots$ & {$[1.557)$} & 7 \\
\hline 14 & 特徴のある & 1.393 & $\cdots$ & 1.463 & {$[1.531]$} & $〔 1.276$ & 1.277 & 1.182 & $\cdots$ & $(1.570)$ & $(1.466]$ & $\cdots$ & 1.201 & 3 \\
\hline 15 & 甘い & $\{1.537\}$ & $\cdots$ & 1.368 & 1.385 & 1.226 & (1.615] & {$[1.431]$} & $\cdots$ & $(1.702)$ & 1.329 & $\cdots$ & [1.712] & 7 \\
\hline 16 & 草のような(グリーン) & 1.366 & $\cdots$ & 1.484 & 1.486 & $(1.595)$ & $(1.723)$ & {$[1.710]$} & $\cdots$ & 1.380 & $\lceil 1.676\rceil$ & $\cdots$ & 1.372 & 8 \\
\hline 17 & 花のような & {$[1.568]$} & $\cdots$ & 1.446 & 1.495 & 1.413 & 1.453 & $(1.865)$ & $\cdots$ & $(1.545)$ & 1.403 & $\cdots$ & $(1.677)$ & 6 \\
\hline 18 & さわやかな & 1.201 & $\cdots$ & $(1.606]$ & 1.399 & 0.997 & $(1.557)$ & {$[1.696]$} & $\cdots$ & 1.484 & $\lceil 1.599]$ & $\cdots$ & 1.291 & 8 \\
\hline 19 & 好き & 1.485 & $\cdots$ & $(1.683)$ & {$[1.787]$} & $\lceil 1.560]$ & $(1.728]$ & {$[1.793]$} & $\cdots$ & $(1.689)$ & $(1.692\}$ & $\cdots$ & $(1.677)$ & 19 \\
\hline 20 & 強い & 1.926 & $\cdots$ & 1.188 & 1.148 & 1.054 & 1.065 & 0.978 & $\cdots$ & 1.258 & 1.021 & $\cdots$ & 1.125 & 0 \\
\hline
\end{tabular}

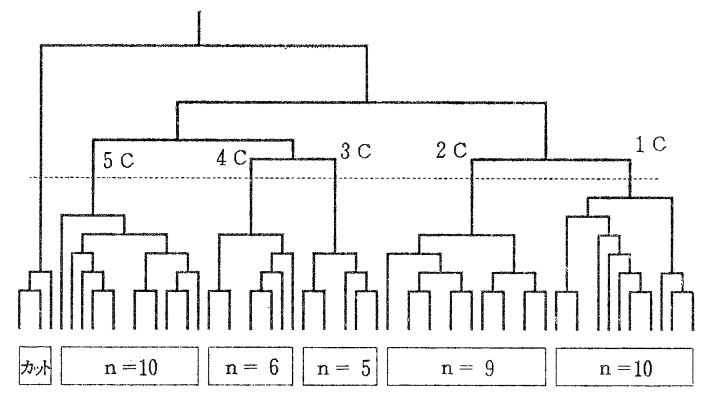

Fig.-4 Resulst of Cluster Analysis Using the Mean Value of 43 Consumers' Data of Liking

専門パネルと 5 クラスターに分類後の官能評価用語に 拈けるパネル間のバラッキ結果を Table-2 に示した。

Table-2 より一般パネル（全）の場合標準偏差 1.5 以 上のものが98コもあったのに対し，クラスター分析後は 約半減し, 標準偏差 1.0 以下のものは10倍以上飞増大し ている。すなわち, 平均值のもつ信頼性が向上し, 集団 のもつ特性值をとの平均值にあずけても不安が減少した ことになる。

一方，専門パネルの場合は標準偏差 1.5 以上のものは 16個とかなり少なく, 標準偏差 1.0 以下のものは 215 二
と非常に多いため，一般パネルより香りの評価に対して 安定しているといら事が言える。

3.4.2 官能評洒用語におけるサンプル識別力の検討 初めに搘好評価点でクラスター分析を行なったのだか ら，嗜好の項目でみてみよう(Table-3)。

一般パネル(全)の場合, レンジは 1.9 , 標準偏差 0.51 とかなりせまい範囲内にサンプル21品が点在し，サンプ 儿間の有意差がつけにくい。ところがクラスター分析に よって分類された各クラスターのレンジと標準偏差をみ ると, レンジで1.5〜2.4倍にひろがり，標準偏差で約 2 倍位大きくなっている。すなわらTable-2の結果から各 クラスターの湠好評価点の標準偏差が小さくなり平均值 の信頼性が向上し, さらにTable-3より 21 品のサンプル 間の点在範井が広がったため, 喍好といら官能評価用語 のサンプル識別能力が向上した事を証明している。

では，搘好によって分類したことが他の官能評価用語 にも同じような事が言光るかどらかみてみる(Table4)。

一般パネル（全）の場合，レンジが 1.5 と小さくサン プル21品がダンゴ状になっている項目 $(\times)$ として，“上 品さ”, “やさしさ”, “華やかさ”, “甘さ”といった4 項目があるが，クラスター分析後の各クラスターのレン ジを見てみると“上品さ”は㐫まりちまくいってない 
香りの表現方法に間する研究（その2）——般パネルと専閉パネルの比較——

Table-2 Proportion of Dispersion in each Group

\begin{tabular}{|c|c|c|c|c|c|c|c|c|c|c|c|c|c|c|c|}
\hline & \multirow{3}{*}{ 項 } & \multicolumn{7}{|c|}{$\sigma \geqq 1.5$} & \multicolumn{7}{|c|}{$\sigma<1$} \\
\hline & & \multirow{2}{*}{$\begin{array}{l}\text { 専 門 } \\
\text { パネル }\end{array}$} & \multicolumn{6}{|c|}{ 一般パ市ル } & \multirow{2}{*}{$\begin{array}{l}\text { 尃門 } \\
\text { パネル }\end{array}$} & \multicolumn{6}{|c|}{ 一般パネル } \\
\hline & & & 全 & $1 \mathrm{C}$ & $2 \mathrm{C}$ & $3 \mathrm{C}$ & $4 \mathrm{C}$ & $5 \mathrm{C}$ & & 全 & $1 \mathrm{C}$ & $2 \mathrm{C}$ & $3 \mathrm{C}$ & $4 \mathrm{C}$ & $5 \mathrm{C}$ \\
\hline 1 & ヤングー アダルト & 1 & 6 & 3 & 5 & 9 & 1 & 4 & 6 & 0 & 3 & 5 & 2 & 10 & 1 \\
\hline 2 & 重い一軽い & 0 & 3 & 0 & 2 & 7 & 0 & 4 & 13 & 0 & 7 & 6 & 2 & 11 & 5 \\
\hline 3 & 上品な一下品な & 0 & 0 & 0 & 0 & 3 & 0 & 0 & 20 & 1 & 9 & 4 & 5 & 15 & 17 \\
\hline 4 & 男性的な 一 女性的な & 0 & 5 & 4 & 4 & 10 & 2 & 3 & 17 & 0 & 5 & 4 & 2 & 9 & 4 \\
\hline 5 & 濃厚なーあっさりした & 1 & 4 & 2 & 3 & 10 & 2 & 5 & 5 & 0 & 4 & 3 & 1 & 11 & 2 \\
\hline 6 & 高級感のある - 安っばい & 0 & 1 & 2 & 1 & 4 & 0 & 0 & 15 & 1 & 11 & 15 & 8 & 16 & 12 \\
\hline 7 & $\begin{array}{l}\text { あきのこない一あきのくる } \\
\text { 洗練された }\end{array}$ & 0 & 7 & 3 & 4 & 8 & 2 & 2 & 10 & 0 & 7 & 1 & 2 & 8 & 5 \\
\hline 8 & 洗練された & 0 & 1 & 0 & 2 & 5 & 0 & 0 & 11 & 0 & 10 & 5 & 5 & 9 & 8 \\
\hline 9 & やさしい & 1 & 4 & 0 & 5 & 7 & 2 & 1 & 10 & 0 & 5 & 2 & 8 & 11 & 9 \\
\hline 10 & 華やかな & 0 & 3 & 3 & 2 & 9 & 1 & 1 & 14 & 0 & 5 & 6 & 4 & 9 & 4 \\
\hline 11 & 清潔感のある & 0 & 4 & 1 & 2 & 10 & 1 & 0 & 14 & 0 & 6 & 4 & 4 & 9 & 6 \\
\hline 12 & 自然な & 2 & 2 & 0 & 5 & 7 & 0 & 1 & 6 & 0 & 2 & 5 & 1 & 12 & 5 \\
\hline 13 & カンキツ系の & 5 & 7 & 6 & 4 & 5 & 5 & 3 & 3 & 0 & 5 & 4 & 6 & 6 & 1 \\
\hline 14 & 特徵のある & 0 & 3 & 3 & 4 & 7 & 5 & 1 & 11 & 0 & 4 & 3 & 4 & 8 & 9 \\
\hline 15 & 甘い & 2 & 7 & 6 & 2 & 10 & 3 & 4 & 12 & 0 & 2 & 3 & 4 & 6 & 7 \\
\hline 16 & 草の上うな & 1 & 8 & 4 & 5 & 10 & 4 & 6 & 6 & 0 & 2 & 3 & 4 & 6 & 7 \\
\hline 17 & 花のような & 2 & 6 & 4 & 4 & 3 & 4 & 0 & 8 & 0 & 3 & 2 & 3 & 7 & 6 \\
\hline 18 & されやかな & 0 & 8 & 0 & 7 & 10 & 4 & 3 & 9 & 1 & 7 & 5 & 4 & 8 & 3 \\
\hline 19 & 嗜好 & 1 & 19 & 5 & 3 & 7 & 4 & 5 & 6 & 0 & 1 & 3 & 5 & 8 & 3 \\
\hline 20 & 強是 & 0 & 0 & 0 & 0 & 0 & 0 & 0 & 19 & 6 & 11 & 15 & 13 & 19 & 14 \\
\hline & 合 & $\begin{array}{l}16 \\
(3.8)\end{array}$ & $\begin{array}{c}98 \\
(23.3)\end{array}$ & $\begin{array}{c}46 \\
(11.0)\end{array}$ & $\begin{array}{c}64 \\
(15.2)\end{array}$ & $\begin{array}{c}141 \\
(33.6)\end{array}$ & $\begin{array}{l}40 \\
(9.5)\end{array}$ & $\begin{array}{c}43 \\
(10.2)\end{array}$ & $\begin{array}{c}215 \\
(51.2)\end{array}$ & $\begin{array}{c}9 \\
(2.1)\end{array}$ & $\begin{array}{c}110 \\
(26.2)\end{array}$ & $\begin{array}{l}106 \\
(25.2)\end{array}$ & $\begin{array}{c}87 \\
(20.7)\end{array}$ & $\begin{array}{c}96 \\
(22.9)\end{array}$ & $\begin{array}{c}122 \\
(29.0)\end{array}$ \\
\hline
\end{tabular}

*数字は個数，（）内は\%表す

が，他の 3 項目はレンジ 2 以上となりサンプル識別能力 が向上したと言えよう。またレンジが1.5〜2.0にあった 項目 $(\triangle)$ b 2 以上となり嗜好という項目でパネルを分 類したことに価値がある事を意味している。

一方, 専門パネルは19項目中15項目は, レンジ 3 以上

（@）となって特り先にも述べたよらにサンプル識別能 力はあると言える。

\section{5 官能評価用語における 専門パネルと一般パネル の一致性の検討}

専門パネルと一般パネルの香水に対する評価の一致性 を相関係数といら值でながめてみると，“ヤングーアダ ルト”, “重い一軽い”, “濃厚一あっさり”, “カンキッ 系の”、“さわやかさ”といった直接的な表現用語に関し てはよく一致しているが，“上品さ”，“高級感”, “洗練 感”といった情緒的概念の項目はどのクラスターとも一 致性が見られず，“あきのこない”，“嗜好”といった好 き，嫌いに関しても同様であった（Table-5)。

一般パネルにわかりやすく説明するため香りを“さわ やかな香り”之“甘い香り”とに分類する場合がある が，今回の実験に和いて“さわやかさ”は一般パネル 一致した評価が得られているが，“甘さ”に関しては一 致性がみられなかった。

“特徴のある”といら項目に対しては，専門パネル， 一般パネルともサンプル21品を和扣むね特徵のあるとい うように評価しているが，相関係数でみてみると低い值
であるため, サンプル21品は特徴があるといら事は一致 するが，21品の順序性に関しては一致性が認められない 事を意味している。

\section{6 香りに対する共通評価因子の探究}

専門パネル抢よび一般パネル，次に一般パネルのクラ スターごとにそれぞれ因子分析を適用し共通因子を求め た (Table-6)。

専門パネル，一般パネルとも 4 因子が抽出され，これ から因子内容を見ていこう。

一般パネルの第I因子は“軽さ，ヤング，あっさり… ・自然”といった項目から成り立って和り「ライト一へ ビー」の軸と各クラスターとも言える。第子以降は クラスターによって順序は異なっているが，“女性的， 甘い, 花のような”といった「ソフトーハード」の軸, “上品さ, 洗練された, 高級感”といった「エレガンス」 の軸, “特徴のある”といった「ユニークネス」の軸と 命名出来る。

專門パネルの場合，第Ｉ因子は一般パネルと同様“ヤ ング，軽い，㐫っさり，…自然な”といった「ライト 一ービー」の概念が得られているが，さらに $3.5 て ゙$ て述べ たように“甘さ，華やかさ”执よび“高級感”の概念が プラスされている。これは，“さわやかさ”に対して“甘 い”といら言葉が反対語とまではいかないが，香りを分 類する場合，第一に“さわやかな香り”之“甘い香り” に分けるため, オリエンタルタイプのよらな重い香りは 
Table-3 Plotting of the Mean Value of 43 Consumers' Data and each of 5 Clustr's Data of Liking.

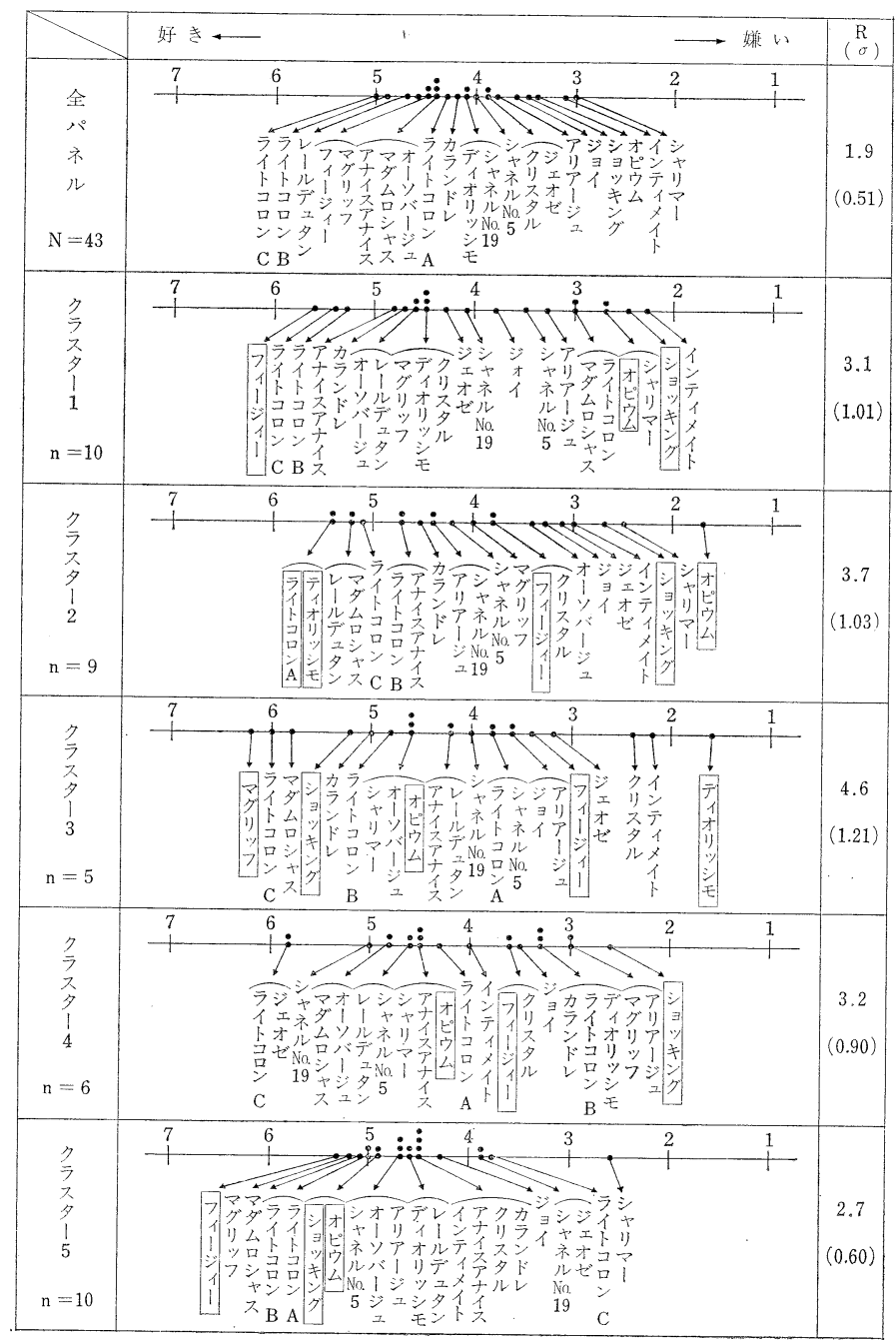

“甘い”と分類され，乙かも専門パネルの場合，香水の 放販価格も知っているため“高級感”といった概念まで 第I因子に現われてきたものと考えられる。一般パネル とやや異なるが「ライト一へビー」の軸と命名してもさ しつか度いであらう。第开因子は“上品な, 女性的, やさしい，花のよらな”といら項目から成り立って拉 り，一般パネルと同様に「ソフトーハード」の軸と命名 する。第亚因子は“特徴の永る，強い”といった項目で あり，「ユニークネス」と命名し，第IV因子は“あきの こない，好き”といった用語であるため「搘好」の軸と 命名する。
次に暏好と因子の関係をとらえてみる。全一般パネル を用いた因子分析の結果でほ第Ｉ因子（ライトーへビー の軸）と嗜好とにかなり高い相関が認められた。次に各 クラスターをみてみると，第 $1 \sim 3$ クラスターは第I因 子（ライトーへビーの軸）と莻好の関係が深く, 第 4 , 5 クラスターは第子（エレガンスの軸）と関係があ る。すなわち，第 1 す 3 クスタ一は軽くてさわやかな 香りを好むのに対して，第 $4 ， 5$ クラスターは上品で洗 練された香りを好んでいる。

ところが専門パネルに拈いては，好き，嫌いが他の官 能評価用語へ影響をあだすず単独で抽出された事は今回 
Table-4 Discriminating Ability of each Sensory Term.

\begin{tabular}{|c|c|c|c|c|c|c|c|c|c|c|}
\hline & \multirow{2}{*}{\multicolumn{2}{|c|}{ 項 }} & \multirow{2}{*}{ 目 } & \multirow{2}{*}{ 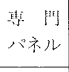 } & \multicolumn{6}{|c|}{ 一般バ采ル } \\
\hline & & & & & 全 & $1 \mathrm{C}$ & $2 \mathrm{C}$ & $3 \mathrm{C}$ & $4 \mathrm{C}$ & $5 \mathrm{C}$ \\
\hline 1 & \multicolumn{3}{|c|}{ ヤング - アダルト } & (1) & O & $\bigcirc$ & (Q) & 0 & (C) & (9) \\
\hline 2 & \multicolumn{3}{|c|}{ 重い一軽い } & (1) & 0 & 0 & (9) & 0 & 0 & 0 \\
\hline 3 & \multicolumn{3}{|c|}{ 止品な一下品な } & $\triangle$ & $x$ & $x$ & $\triangle$ & $\mathrm{O}$ & $\triangle$ & $\triangle$ \\
\hline 4 & \multicolumn{3}{|c|}{ 男性的な 一 女性的な } & (Q) & $\triangle$ & 0 & (c) & (C) & 0 & 0 \\
\hline 5 & \multicolumn{3}{|c|}{ 濃厚な一あっさりした } & (a) & O & 0 & (9) & () & 0 & $\bigcirc$ \\
\hline 6 & \multicolumn{3}{|c|}{ 高級感のある一安っばい } & 0 & $\triangle$ & $\triangle$ & 0 & (9) & $\triangle$ & 0 \\
\hline 7 & \multicolumn{3}{|c|}{ あきのこない一あきのくる } & 0 & $\triangle$ & 0 & 0 & () & 0 & 0 \\
\hline 8 & \multicolumn{3}{|c|}{ 洗練された } & 0 & $\triangle$ & $\triangle$ & 0 & 0 & 0 & 0 \\
\hline 9 & \multicolumn{3}{|c|}{ やさしい } & () & $x$ & $\mathrm{O}$ & (0) & (9) & 0 & 0 \\
\hline 10 & \multicolumn{3}{|c|}{ 華やかな } & (1) & $x$ & $\triangle$ & 0 & 0 & $\triangle$ & 0 \\
\hline 11 & \multicolumn{3}{|c|}{ 清潔感のある } & () & 0 & (C) & (0) & () & O & 0 \\
\hline 12 & \multicolumn{3}{|c|}{ 自然な } & (c) & 0 & 0 & (a) & (c) & 0 & $\triangle$ \\
\hline 13 & \multicolumn{3}{|c|}{ カンキツ系の } & () & ( & (9) & (9) & () & (9) & (C) \\
\hline 14 & \multicolumn{3}{|c|}{ 特徴のある } & (C) & $\triangle$ & $\triangle$ & $\mathrm{O}$ & 0 & $\bigcirc$ & $\triangle$ \\
\hline 15 & \multicolumn{3}{|l|}{ 甘い } & (1) & $x$ & 0 & 0 & (9) & $\triangle$ & 0 \\
\hline 16 & \multicolumn{3}{|c|}{ 草のような } & (0) & $\triangle$ & 0 & 0 & () & 0 & 0 \\
\hline 17 & \multicolumn{3}{|c|}{ 花のような } & () & $\triangle$ & 0 & () & (c) & 0 & 0 \\
\hline 18 & \multicolumn{3}{|c|}{ さわやかな } & () & 0 & (O) & (O) & 0 & 0 & 0 \\
\hline 19 & \multicolumn{3}{|c|}{ 惰好 } & () & $\triangle$ & (9) & (O) & (O) & (9) & 0 \\
\hline \multirow[t]{5}{*}{20} & \multicolumn{3}{|l|}{ 強㫕 } & & & & & & & \\
\hline & () & & 数 & 15 & 1 & 5 & 11 & 12 & 5 & 2 \\
\hline & 0 & の & 数 & 3 & 6 & 9 & 7 & 7 & 10 & 14 \\
\hline & $\triangle$ & $\infty$ & 数 & 1 & 8 & 4 & 1 & 0 & 4 & 3 \\
\hline & $\times$ & の & 数 & 0 & 4 & 1 & 0 & 0 & 0 & 0 \\
\hline 潘 & $\begin{array}{r}\mathrm{R} \\
.5 \leqq \mathrm{R}\end{array}$ & $5: \times$ & $3.0 \leqq R$ & $\begin{array}{c}0: \\
:\end{array}$ & & & & & & \\
\hline
\end{tabular}

Table-5 Degree of Correspondence between Perfumers and Consumer by Correlelation Coefficient

\begin{tabular}{|c|c|c|c|c|c|c|c|c|}
\hline & \multicolumn{2}{|c|}{ 项 } & 全八祙 & $1 \mathrm{C}$ & $2 \mathrm{C}$ & $3 \mathrm{C}$ & $4 \mathrm{C}$ & $5 \mathrm{C}$ \\
\hline 1 & \multicolumn{2}{|c|}{ ヤングーアダルト } & (O) & 0 & 0 & & $\triangle$ & $\triangle$ \\
\hline 2 & \multicolumn{2}{|c|}{ 重い一軽い } & 0 & $\triangle$ & 0 & & 0 & $\triangle$ \\
\hline 3 & \multicolumn{8}{|c|}{ 上品な 一下品な } \\
\hline 4 & \multicolumn{2}{|c|}{ 男性的な 一 女性的な } & $\triangle$ & $\triangle$ & & & & \\
\hline 5 & \multirow{2}{*}{\multicolumn{2}{|c|}{$\begin{array}{l}\text { 澧厚なーあっさりした } \\
\text { 高級感のある一安っぱい }\end{array}$}} & 0 & 0 & 0 & & 0 & $\triangle$ \\
\hline 6 & & & & & & & & \\
\hline 7 & \multicolumn{2}{|c|}{ あまのこない一忍きのくる } & & & & & & \\
\hline 8 & \multicolumn{2}{|c|}{ 洗練された } & & & & & & \\
\hline 9 & \multicolumn{2}{|c|}{ やさしい } & $\triangle$ & 0 & & & & \\
\hline 10 & \multicolumn{2}{|l|}{ 華やかな } & $\triangle$ & & & & $\triangle$ & \\
\hline 11 & \multicolumn{2}{|c|}{ 清潔感のある } & 0 & 0 & 0 & & & \\
\hline 12 & \multicolumn{2}{|c|}{ 自然な } & $\triangle$ & $\triangle$ & & & & \\
\hline 13 & \multicolumn{2}{|c|}{ カンキツ系の } & 0 & $(0)$ & $\triangle$ & & $\triangle$ & 0 \\
\hline 14 & \multicolumn{2}{|c|}{ 特徵のある } & & & & & & \\
\hline 15 & \multicolumn{2}{|c|}{ 甘い } & & & & & & \\
\hline 16 & \multicolumn{2}{|c|}{ 草のような } & 0 & 0 & & & & \\
\hline 17 & \multicolumn{2}{|c|}{ 花のような } & $\triangle$ & $\triangle$ & 0 & & & \\
\hline 18 & \multicolumn{2}{|c|}{ さわや゙かな } & (O) & $(\mathrm{O}$ & 0 & & $\Delta$ & $\triangle$ \\
\hline 19 & \multicolumn{2}{|c|}{ 嗜好 } & & & & & & \\
\hline \multirow[t]{4}{*}{20} & \multicolumn{2}{|l|}{ 強さ } & & & & & & \\
\hline & (2) & 数 & 2 & 2 & 0 & 0 & 0 & 0 \\
\hline & 0 & の 数 & 5 & 5 & 6 & 0 & 2 & 1 \\
\hline & $\Delta$ & $\infty \quad$ 数 & 5 & 4 & 1 & 0 & 4 & 4 \\
\hline
\end{tabular}

$* 0.9 \leqq \mathrm{r} \cdots \cdots \odot, 0.8 \leqq \mathrm{r}<0.9 \cdots \cdots, 0,0.7 \leqq \mathrm{r}<0.8 \cdots \cdots \Delta$

の実験の大きな収穫であった。すなわち，一般パネルは 坶き，嫸いが香りの評洒化大き影響していることに対

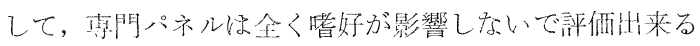
といら事を物語っている。
Table-6 Results of Factor Analysis (Perfuner and consumer)

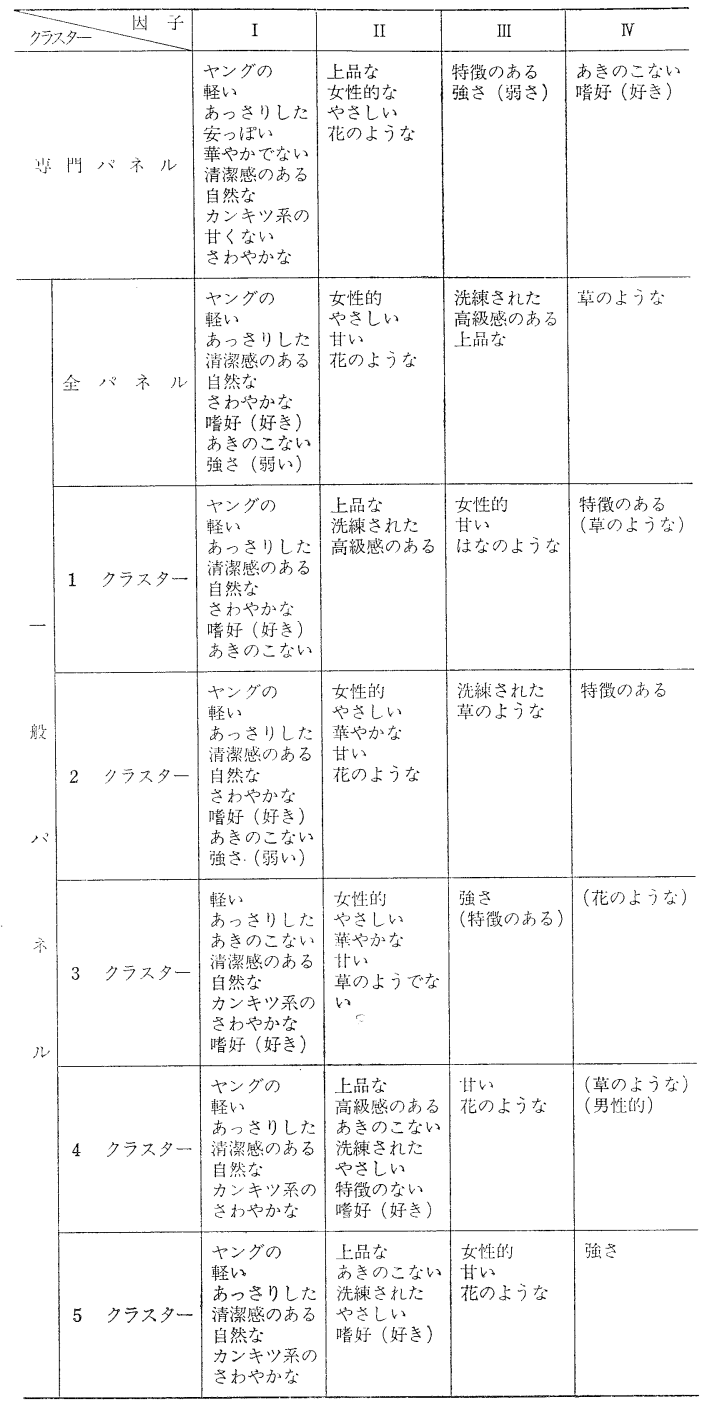

\section{4. 総 括}

1) 専門パネルは一般パネルと比較して, パネル間のバ ラツキも少なく，サンプル識別能力るあると言える。

2）一般パネルは嗜好といらものが評洒に対し大きく影 響しているため分類（層別）する必要がある。

3）今回の実験に扔いて一般パネルは 5 クラスターに分 類江来た。

4) 一般パネルを分類することによって，パネル閒のバ ラッキは減少し，サンプル識別能力は向上した。 


\section{粧 技 誌 第 20 巻第 3 号 1987}

5）専門パネルと一般パネルの評価に和いて，一致性の 認められる用語と認められない用語が明確になった。

6) 香りに対する評価概念として，4 因子が専門，一般 パネルとも抽出された。

7）嗜好に対する概念が専門，一般パネル間で大さく異 なって物り，一般パネルでは“軽く，さわやかな”香 りを好を層と, “上品で, 洗練された”いわゆるエレ ガンスな香りを好を層とに分かれ，専門パネルでは喍 好という軸が単独で抽出され，好き，嫌いが他の官能 評価用語に対して影響をあたえない事がわかった。

\section{参考文献}

1）池山，小柳，宮下，“創香に和けるイメージ展開 技法の開発”, J. Soc. Cosmet. Chem. Japan. Vol. 18, No.1 (1984)

2）小柳, 堀越, 山川, “香りの表現方法に関する研 究”第27年度官能検查シンポジウム報文集（日科 技連), p. 75 ～88 (1986)

（昭和 62 年 3 月 9 日受理） 